\title{
PRICE ADJUSTMENT IN COSTA RICA: A FIRST ASSESSMENT USING MICRO-DATA
}

\author{
Alberto José Vindas Quesada ${ }^{1}$
}

Recibido: 25/05/2014

Aprobado: 08/10/2014

\begin{abstract}
This article explores the pricing adjustment process in Costa Rica, taking a deeper look into the micro-data that make up the Consumer Price Index for the period 2006-2013. The basic question asks if this process resembles time-dependent picing models, or if it resembles more a state-dependent process. This is done analysing a series of random effects regressions to explore the relations between inflation rate, frequency of pricing adjustments and their average magnitude. The main conclusions are that 1) there is considerable heterogeneity between product categories, 2) price decreases follow a very stable pattern that does not depend on the overall inflation rate, 3) the average size of the price increases is influenced by a very small magnitude by the inflation rate, 4) the proportion of prices increasing each month is strongly positively correlated with the inflation rate, and 5) state-dependent specifications fit better these facts.
\end{abstract}

KEY WORDS: INFLATION, MACROECONOMICS, ECONOMIC CYCLE, MONETARY POLICY, PRICE RIGIDITY, CPI

\section{RESUMEN}

Este artículo explora el proceso de ajuste de precios en Costa Rica, dando una mirada más detallada a los microdatos que componen el Índice de Precios al Consumidor para el periodo 2006-2013. La pregunta básica es si este proceso se asemeja a uno dependiente del tiempo, o a uno dependiente del estado. Esto se hace analizando una serie de regresiones de efectos aleatorios para explorar las relaciones entre tasa de inflación, frecuencia de ajuste de precios y su magnitud promedio. Las principales conclusiones son que: 1) hay considerable heterogeneidad entre las categorías de producto, 2) las reducciones de precio siguen un patrón muy estable que no depende de la tasa de inflación, 3) el tamaño promedio de los aumentos de precio es afectado levemente por la tasa de inflación, 4) la proporción de precios aumentando cada mes tiene una fuerte correlación positiva con la tasa de inflación, y 5) una especificación dependiente del estado refleja mejor estos hechos

PALABRAS CLAVE: INFLACIÓN, MACROECONOMÍA, CICLO ECONÓMICO, POLÍTICA MONETARIA, RIGIDEZ DE PRECIOS, IPC

1 Universidad de Costa Rica; Banco Central de Costa Rica, Código Postal 10058-1000, Costa Rica; albertojose.vindas@ucr.ac.cr 


\section{INTRODUCTION}

Nominal rigidities are at the heart of the New Keynesian framework. One of the most popular ways in which these are implemented is price rigidity, which gives rise to the monetary non-neutrality central to this class of models. In the last years a series of studies using extensive and unpublished data from several consumer price indexes (CPI) have unveiled new information on the price adjustment process. Analysing several thousands of price quotes, different patterns and new questions have been established.

This brief study contributes to the literature by doing an exploration of the price adjustment process in Costa Rica. This is the first time a study of this sort has been carried out with Costa Rican data due the confidentiality constraints surrounding a nationwide dataset such as the one gathered to calculate the $\mathrm{CPI}^{2}$.

The main focus of this study is to assess whether the pricing adjustment process follows more closely a time-dependent specification or a state-dependent one. Answering a relatively straightforward question does this: how big and how frequent are price changes, and how do these react to the overall inflation rate? Random effects models are used for this purpose, separating the cases for price increases and decreases which prove to be of critical importance.

The evidence suggests that a statedependent specification is more satisfactory than a time-dependent one. This is reflected by the fact that what varies the most in time is the fraction of price quotes increasing, while the fraction of price quotes decreasing and the average relative size for both increases and decreases do not vary significantly in time. The fraction of price increases is strongly positively correlated with the overall inflation rate, which gives support to a state-dependent pricing adjustment model. These findings closely resemble the ones found for different countries with lower and more stable inflation rates.

2 Due to this, we greatly acknowledge the kind collaboration of the National Census and Statistics Institute of Costa Rica for providing the database.
This study is made up of nine sections, the first of which is this introduction. The second one discusses briefly the leading models of price rigidity. The third section has a literature review on the empirical studies of price rigidity using micro data. Section four describes the Costa Rican setting, while the fifth describes the dataset used. The sixth section provides an exploratory inspection of the data and the seventh presents the econometric analysis. The eighth section discusses the results and the ninth and final section concludes.

\section{THEORETICAL FRAMEWORK}

\section{A) The Case for Sticky Prices in Macroeconomics}

According to Snowdon and Vane (2005), New Keynesian economics revolves around two important questions in macroeconomics: "Does the theory violate the classical dichotomy? That is, is money non-neutral?" and "Does the theory assume that real market imperfections in the economy are crucial for understanding economic fluctuations?" (Snowdon and Vane, 2005 , p. 363). An important feature of macroeconomic modelling deals with observing the aggregate data and telling a story with a model. These should include elements consistent with how we believe the markets function, and as Walsh (2010) puts it, in macroeconomics most of the short run non-neutrality is not rationalised using imperfect information, or incomplete participation in financial markets, but introducing nominal rigidities.

Galí and Gertler (2007) argue that the recent vintage of macroeconomic models bring to the table a mixture between elements of the real business cycle theory and the New Keynesian theory: quantitative modelling built from microfoundations that include nominal price stickiness. Because of this, they mention, the three most important additions to the real business cycle models are money, monopolistic competition, and nominal rigidities. In these models, money works as a unit of account (since we're now explicitly inserting the nominal sector), monopolistic competition 
is required to add a certain degree of price setting capacity by firms, and the nominal rigidities are the friction that give rise to the short run non-neutrality of money.

\section{B) Time-Dependent Price Setting}

As its name suggests, these models have a strong dependence on the time factor to perform adjustments. One of the earliest models in this fashion that took into account rational expectations was presented by Taylor (1980). Calvo (1983) provides an alternative to rationalise these rigidities: having firms changing prices only if they receive a signal to do so. This "Calvo fairy" assumption requires having a Poisson process determining the proportion of prices that will change each period.

In New Keynesian models, the latter has become one of the most popular workhorses because of its ease of implementation and analysis. It still is widely used, but the new evidence on pricing adjustment tends to cast some scepticism on it because of the abstractions it makes: "While few macroeconomists would argue for this model as a literal description of how firms set prices, the goal of this 'Calvo model' is to provide a tractable model of price adjustment to be incorporated into general equilibrium business cycle models" (Nakamura and Steinsson, 2013, p. 8). Woodford (2008) comes to the defence of this specification, arguing that in the presence of high informational costs, the Calvo model proves to be a good enough approximation to the dynamics presented in more elaborate models.

\section{C) State-Dependent Price Setting}

State-dependent models rely on factors different from time to determine how firms decide to change prices. Its name is also suggestive of the fact that these models will take into account the state of the economy when taking pricing decisions. A popular example in this class of models was proposed by Rotemberg (1982). As Kashyap (1995) notes, firms decide not to continually adjust their prices and let inflation erode its set price because of the adjustment costs. This is a cost that is usually assumed fixed, and the policy followed by firms is to adjust their prices until a certain lower bound in their relative price is reached

In these state-dependent models the timing of the adjustments is also endogenised, and as such price changes can take place in two dimensions: the extensive and intensive margin. The first one refers to the fact that after an inflationary shock, firms will react to it by increasing the size of the price changes. This is the only effect that is expected from timedependent models, and the state-dependency includes the extensive margin. This margin opens the possibility that with the same inflationary shock, there will also be more firms changing their prices, so the adjustment will take place in both frequencies and magnitudes.

Regarding state-dependent models, it can be noted that these "are generally less tractable than time-dependent models, thus accounting for their less frequent use. And prior to the availability of microeconomic data on price changes, time-dependent models were seen as adequate for modelling aggregate phenomena" (Walsh, 2010, p. 244). Now that more microeconomic data has been made available, research on these models has taken up as exemplified by Golosov and Lucas (2007).

\section{D) Measuring Price Rigidity: Enter the Micro Evidence}

An early attempt to measure price rigidities was performed by Cecchetti (1986) while looking at magazine data to assess evidence in favour of monopolistic sticky prices. In his interpretation of the yearly data, state-dependent models resemble more the observed relation between the inflation rate and the frequency of adjustment. Kashyap (1995) performed another exercise trying to measure size, frequency and synchronisation of the price changes of a selected group of goods from catalogue sales. His findings are also more supportive of state-dependent models, in the sense that his basket of goods has more frequent price changes when the inflation rate is higher. A particular weakness of these studies has to do with 
the periodicity of the data (annually and semiannually) and the sectors they cover (magazines and retail catalogue products). Because of this, extending their conclusions to the general economy might be misleading due to their idiosyncratic nature.

Years later, Bils and Klenow (2004) came into the game to set a new standard for micro evidence when it comes to the study of price rigidity. Instead of focusing on particular products, or even markets, they analysed the nonshelter component of the CPI in the United States using data from the Bureau of Labour Statistics for the period 1995-1997. After this, a new wave of studies performing similar analyses emerged: Klenow and Kryvtsov (2008) extend the analysis from 1988 to 2004; Nakamura and Steinsson (2008) complement these findings with its Producer Price Index (PPI) counterpart. In the Euro area, some examples are Aucremanne and Dhyne (2004), Dhyne et al. (2005), and Álvarez et al. (2005).

One common factor of the United States and the Euro area is the low inflation rate prevailing in the last years, which is well recognised concern in literature surveys: "the U.S. sample has the disadvantage of a low and stable inflation rate, which is not ideal for making inference about the relationship between the frequency of price change and inflation" (Nakamura and Steinsson, 2013, p. 18). A natural question that rises has to do with the existence of a threshold that would break these results: how volatile should the environment be to disrupt this stable pattern?

\section{E) Pump Up the Inflation}

To have a better understanding of how the state of the economy might be affecting price adjustment dynamics, several efforts have been directed towards analysing more volatile time periods for different countries. Medina et al. (2007) undertake the Chilean evidence for CPI data, as Palmero and Chacón (2011) do for the Bolivian case.

Gagnon (2009) provides a notable example on the Mexican case, which covers a convulse period including inflation rates of over
$40 \%$, and a low and stable inflation towards the end of the period. His results give support for both time-dependent and state-dependent models if the total period is divided on high and low inflation sub-periods. He claims that during high-inflation periods (above a 10-15\% threshold) the behaviour of the price adjustment process resembles more a state-dependent; and when in low-inflation periods, it is more similar to the predictions that would arise from a time-dependent framework. Álvarez et al. (2013) study Argentinian evidence for the period 1988-1997, which includes a hyperinflationary episode where annual inflation rates exceeded $1000 \%$. They find that the frequency of price adjustments is nearly uncorrelated if the inflation rate is below $10 \%$.

\section{F) Meet the Costa Rican Inflation}

In the recent economic history of Costa Rica, the worst episode can be traced back to the early 1980s. Following a highly interventionist and entrepreneurial government scheme, the country fell victim to a debt crisis similar to many other Latin American countries. After this stage, Lizano (2007) considers that Costa Rica has been successful in avoiding crises, and by many measures this is true. Following the stabilisation of the country after the crisis episode, the country did not suffer exchange rate crises, or any other relating to the balance of payments or inflationary outbursts. In his view as former president of the institution, he relates that from 1982 until 2004, the Central Bank interpreted its main mandate to prevent these events. This meant placing other of the mandates of the institution in a second plane.

Delgado (2010) refers to one of these relegated objectives: price stability. $\mathrm{He}$ describes it as a chronic inflation, inherited from the debt crisis and other unresolved structural factors, particularly the quasifiscal losses that the Central Bank had to take over. He splits the 1983-2009 period into two sub-periods: the first one ranges from 1983 to 1996 , where the inflation rate was high and volatile (mean $17.2 \%$ and standard 
deviation 6.1), and the second one from 1997 to 2009 where the inflation behaviour was better (mean $10.8 \%$ and standard deviation 2.6). Figure 1 presents the inflation rate using CPI data up to February 2013, where a third episode is easily spotted. The inflation rate from 2010 has been remarkably stable and considerably low (mean 5.1\% and standard deviation 0.6) in comparison to the other sub-periods.

FIGURE 1

COSTA RICA: INFLATION RATE

1998-2013

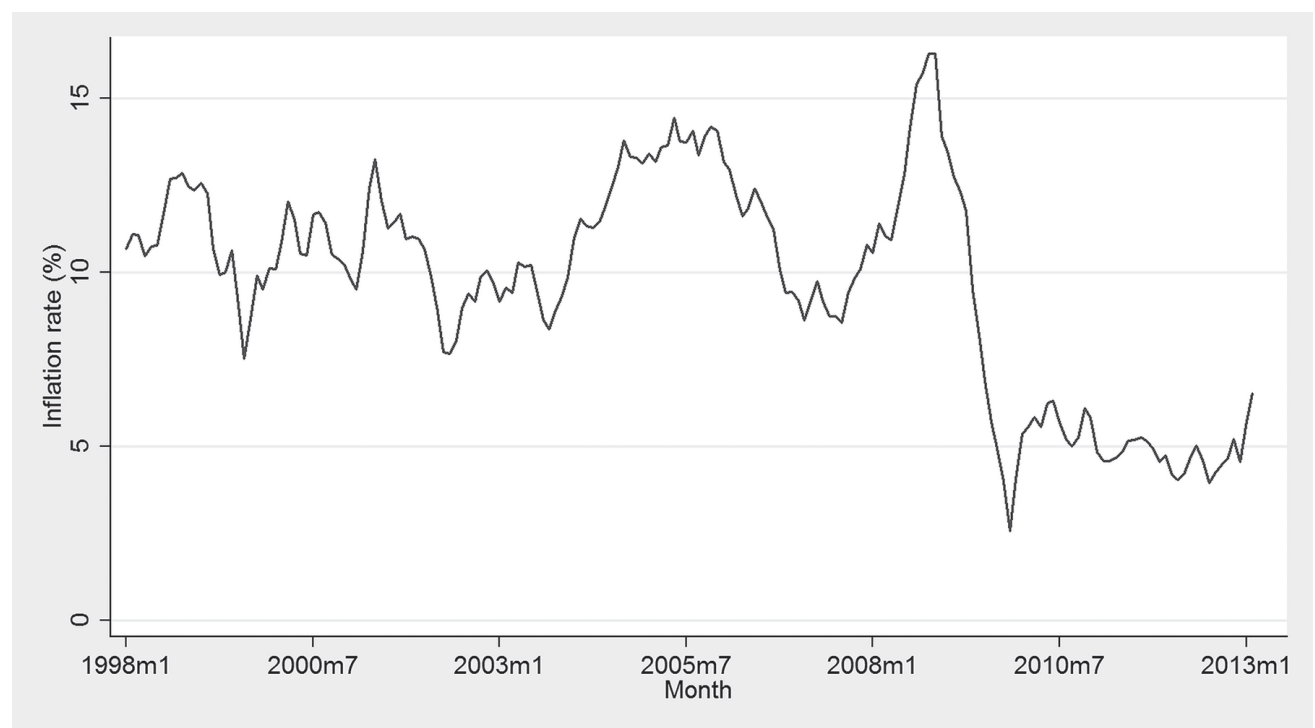

Source: compiled by author

This reduction in the inflation rate did not come by accident. In October 2006, the exchange rate regime went from a predictable crawling peg that prevailed for the last two decades to a crawling band system. These crawling bands are the system currently in place, and its implementation was envisioned as an intermediate step towards a managed float regime. These steps are part of the medium term strategy of the institution to consolidate an explicit inflation-targeting regime. This change helped reduce the inflationary inertia reflected in the data, since the daily devaluation was highly predictable and the pass-through coefficients of the exchange rate were high ${ }^{3}$.

$3 \quad$ León et al. (2002) study this issue for the period 1991-2001 and find a pass-through coefficient of 68 and $52 \%$ for tradable and non-tradable goods, respectively.
This, in conjunction with low demand pressures from outside the country helped position the inflation rate at such low and stable values.

This turn of events provide an interesting setting to study how the price adjustment process reacts to changes in the economic environment. How strongly did the frequency and magnitude of price changes react to the inflation rate?

\section{DATA AND METHODOLOGY}

\section{A) Data}

The data we use correspond to the monthly unpublished data gathered by the National Census and Statistics Institute of Costa Rica to construct the CPI. The base month for the current CPI series is July 2006, 
and the time period cover ranges from August 2006 to February 2013. Approximately 10000 quotes are recorded each month, and the total amount of continuous price quotes for its nonshelter component is 784179. The goods selected for the CPI were the ones that represented a total expenditure of at least $0.05 \%$ or were bought by at least $5 \%$ of the households in the 2004 National Income and Expenditure Survey, and they account for $88.5 \%$ of the reported expenditures ${ }^{4}$.

For the purposes of this study, the goods are grouped into 73 different categories that correspond to the subclasses proposed in the United Nations Classification of Individual Consumption According to Purpose. With this information we create a panel consisting of 78 months. The other variables of interest are the proportion of the price increases and decreases, and the average relative size of these changes. The proportions are simply computed as the fraction of price quotes that increased or decreased over the total amount of quotes. The size of the price changes are expressed in logarithmic terms, and as such should be interpreted as a relative price (i.e., a relative price of 1.1 represents a $10 \%$ increase while a relative price of 0.9 means a $10 \%$ price drop).

\section{B) Methodology}

Given that the database allows us to follow the 73 categories over time, we are in a position where we can use panel data methods to control for unobserved heterogeneity. We assume a model of the form:

$$
y_{i, t}=x_{i, t} \beta+c_{i}+u_{i, t} \quad t=1, \ldots, T
$$

Where denote the vector of regressors at time $t$ for category $i$. Notice that in this formulation, both and are unobserved, so controlling for this fact is key for panel data methods. Assuming strict exogeneity of the regressors, this is:

$$
E\left(u_{i, t} \mid x_{i, 1}, \ldots, x_{i, T}, c_{i}\right)=0 \quad t=1, \ldots, T
$$

$4 \quad$ More information on the methodology of this index and its characteristics can be found in INEC (2006a) and INEC (2006b).
We get that

$E\left(y_{i, t} \mid x_{i, 1}, \ldots, x_{i, T}, c_{i}\right)=x_{i, t} \beta+c_{i} \quad t=1, \ldots, T$

We must also make assumptions on the relationship between this unobservable variable and the regressors so the identification strategy yields the best possible estimators. The two alternatives are a random effects specification and a fixed effects specification, and the distinction lies on whether the unobservable variable is mean independent of the regressors. The former assumes that these are mean independent, while the latter assumes there is a relation.

Since the distinction between fixed and random effects is a critical one, we must be sure to use the correct specification since the wrong choice could lead to inconsistency or efficiency losses. For this choice, we perform a Hausman test, where the alleged efficiency of a consistent fixed effects estimator is examined.

\section{RESULTS}

\section{A) A Graphical Examination of the Pricing Adjustment}

When using micro data most of the studies take advantage of the heterogeneity that is embedded in the different product categories. As such, the first step when examining the dataset is to look for traces of significant differences across the categories. Figure 2 does precisely this. It presents four different histograms summarising the distribution of the relative sizes of price increases and decreases, and also that of the fraction of products that are increasing and decreasing their prices.

These histograms depict the average figures during the entire period of study. The averaging is eliminating the time dimension, and because of this only the total results for each category are shown. The histograms tell us that across the product categories, there are notable differences in how the sizes and proportions of price changes are distributed. Since this is a feature that is carried over the entire time dimension, it is reasonable to believe that there is indeed heterogeneity in these products. As such, this heterogeneity should be, in principle, accounted for in the econometric analysis. 


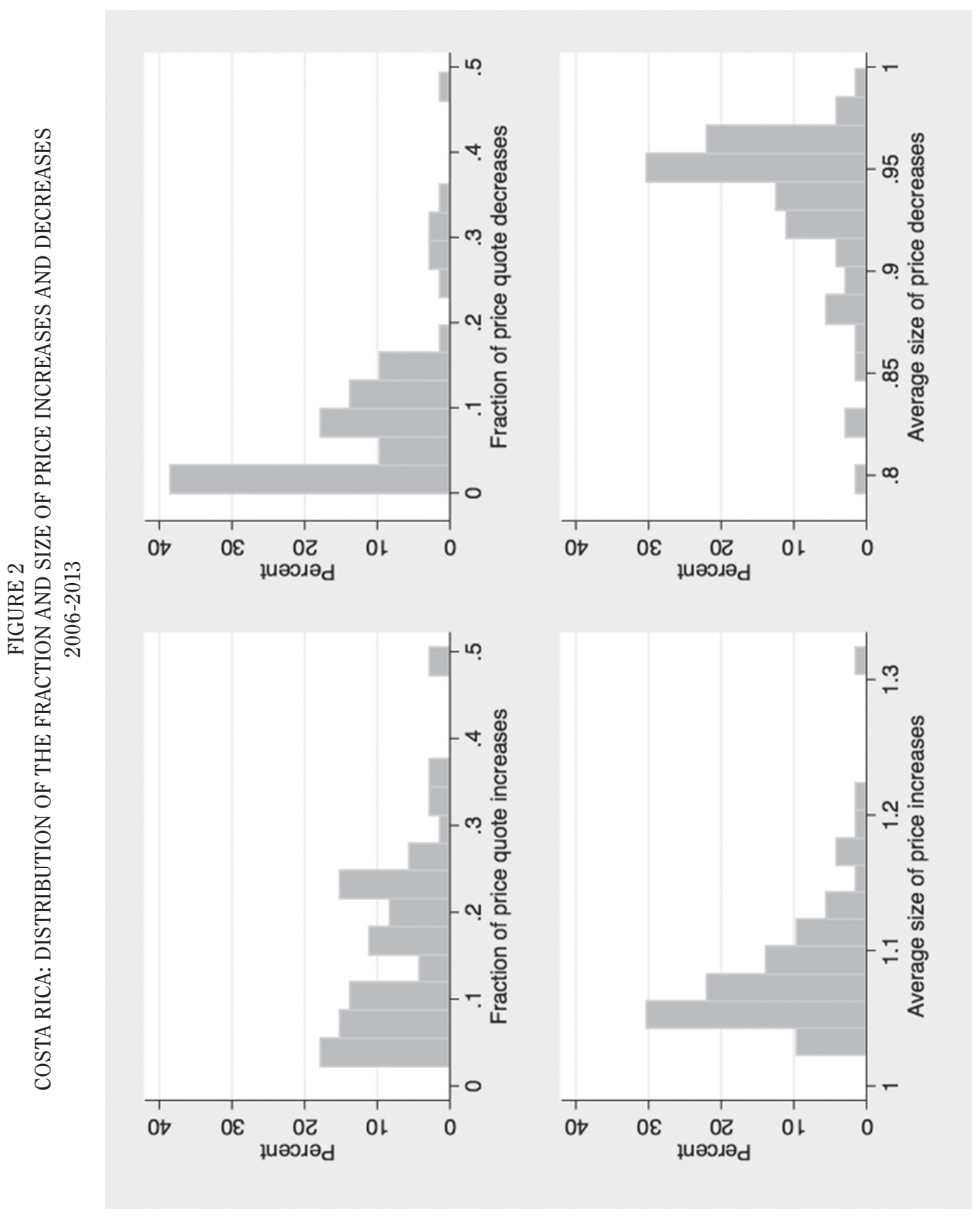


Before continuing with the econometric formulation it is sensible to explore the facts that are getting evaluated with the econometric model. This is to see the results these facts suggest, and if they seem to be in line with those of other studies. One way to do this is to plot the aggregate averages in time. Figure 3 does this for the average size of the price quote changes. Surprisingly enough, both the average size of price increases and decreases are very stable in time. This is a result that is consistent with those of economies without high inflation. The fact that for a long time Costa Rica did not have a relatively high inflation rate, or was particularly volatile might have helped stabilise the frequency before 2009. However, it is noteworthy to highlight that after this year, it follows the same pattern, even when the inflation rate halved and achieved an unprecedented stability.

FIGURE 3

COSTA RICA: AVERAGE PRICE CHANGE

2006-2013

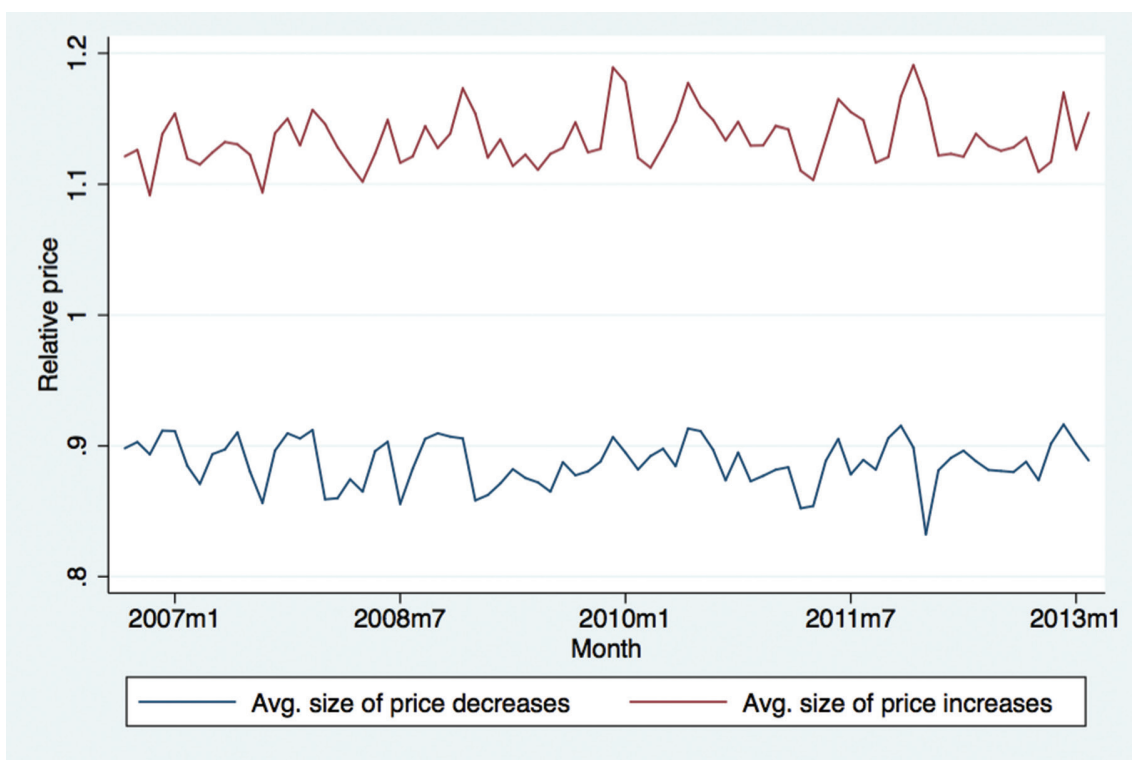

Source: compiled by author

The second aspect considered in this kind of studies is the relation between the frequency of the price changes and the inflation rate. This is presented in Figure 4 and confirms a pattern already documented in different settings: price decreases are not related to the overall inflation rate in nonhigh inflation settings and price increases are highly influenced by it. This would reinforce the notion that price decreases (at least in the absence of a particularly high inflation rate) appear to have a life of their own, irresponsive to aggregate conditions. The fraction of price quotes increasing, on the other hand shows a very clear and positive relation to the inflation rate. Looking at these pieces of evidence, it appears as if the whole priceadjustment process in Costa Rica was driven almost wholly by the frequency with which prices are increased. 
FIGURE 4

COSTA RICA: FREQUENCY OF PRICE CHANGE AND INFLATION RATE $2006-2013$

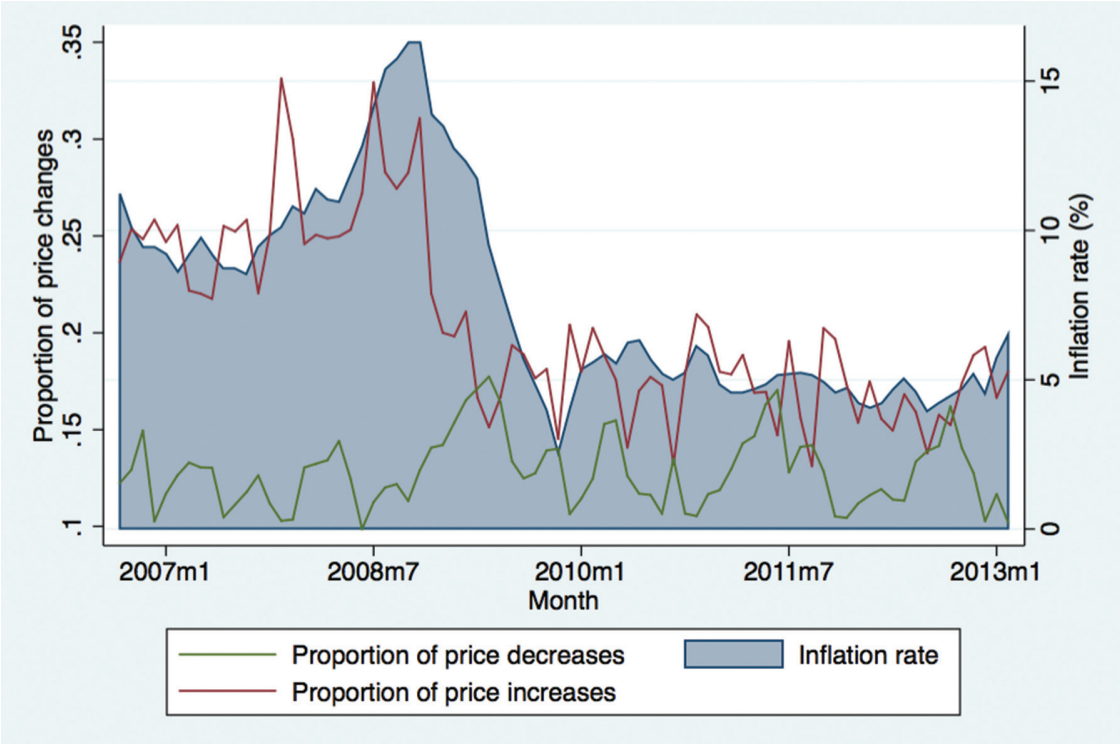

Source: compiled by author

\section{B) Econometric Analysis}

To study the effects of the inflation rate on the average size and fraction of price changes, we depart using a fixed effects model. The model simply regresses the size or fraction of price changes to the inflation rate and the standard time trend to capture other time-varying elements. This specification allows taking into account unobservable heterogeneity in the 73 subclasses and a possible endogeneity problem. This heterogeneity can be expected since the goods have varying cost structures and input intensities, and was already confirmed to be present in the previous section. Table 1 presents the results of these fixed effects regressions.

TABLE 1

COSTA RICA: FIXED EFFECTS ESTIMATIONS SUMMARY 2006-2013

\begin{tabular}{lccccc}
\hline Dep. variable & Inflation coef. & Std. Error & P-value & F-stat $(1,72)$ & P-value \\
\hline Size increase & 0.000966 & 0.000364 & 0.0100 & 7.04 & 0.0098 \\
Size decrease & -0.000167 & 0.000432 & 0.6990 & 0.15 & 0.6995 \\
Proportion increase & 0.009176 & 0.000612 & 0.0000 & 225.00 & 0.0000 \\
Proportion decrease & 0.000132 & 0.000505 & 0.7940 & 0.07 & 0.7941 \\
\hline
\end{tabular}

Source: compiled by author 
A first glimpse at these results confirms what was already suspected from the graphical treatment of the data. Price decreases are not particularly influenced by the inflation rate. Not only the coefficients associated with the inflation rate are not significant, but the entire regression does not seem to be significant as well ${ }^{5}$. Price increases, on the other hand, tell a different story. Both the coefficients associated to inflation and the overall models are statistically different from zero. Because of this, the attention is now focused on the dynamics of price increases, as price decreases seem to be irresponsive to the overall inflation rate.

The first step is to perform a Hausman test to see whether the unobservable characteristics in each subclass justify controlling for them by performing the "within" transformation. For this we use an equivalent form to the Hausman test as described in Schaffer (2005). The test gives a $p$-value of 0.2545 for the proportion of price increases and 0.7857 for the average size of the price increases. Since the difference in the estimates is not statistically significant, we can't reject that a random effects estimation gives an efficient result. These test results suggest discarding the fixed effects models to focus on the random effects ones. The alternative random effects estimation results are presented in Table 2 , and remain virtually the same as in the fixed effects model (which suggest the lack of endogeneity problems in the variables).

TABLE 2

COSTA RICA: RANDOM EFFECTS ESTIMATIONS SUMMARY 2006-2013

\begin{tabular}{lccccc}
\hline Dep. variable & Inflation coef. & Std. Error & P-value & Chi-stat (1) & P-value \\
\hline Size increase & 0.000967 & 0.000217 & 0.000 & 19.85 & 0.0000 \\
Size decrease & -0.000161 & 0.0001781 & 0.366 & 0.820 & 0.3664 \\
Proportion increase & 0.009176 & 0.000468 & 0.000 & 384.49 & 0.0000 \\
Proportion decrease & 0.000132 & 0.0002938 & 0.653 & 0.20 & 0.6532 \\
\hline
\end{tabular}

Source: compiled by author

A final specification test has to do with the presence of heterogeneity over the article subclasses. This is to determine whether there is convincing statistical evidence as to support a random effects specification, or if the evidence suggests discarding unobserved heterogeneity. The Breusch-Pagan Lagrange Multiplier test gives a $p$-value of 0.000 for both the proportion and average size of price increases. This is not surprising as the graphical treatment of the last section strongly suggested differences across the product categories. This final test confirms that a random effects model is the appropriate tool for analysis.

\footnotetext{
$5 \quad$ Carrying out an analysis for the model in first
} differences leads to the same conclusions.

\section{C) Discussion}

The results thrown by the random effects regressions prove to be very interesting ones that add to the existing stock of information on the price adjustment process. For a long part of its history, Costa Rica has had a moderate inflation rate, and that was particularly the case during the 19982009 period. During these years a series of events struck the economy, one of them being a structural change of the magnitude of an exchange rate regime switch. The price adjustment dynamics show a very clear pattern throughout the period of analysis, even when having evidenced important changes in the economy. 
The distinction between the behaviour of price increases and decreases stressed in Gagnon (2009) proves to be of critical importance. Both the graphical and econometric examination of the data show that these two respond to very different processes. Price decreases, as evidenced for different countries, are not rare phenomena. On average, $12.82 \%$ of price quotes every month show decreases, with a magnitude of $11.27 \%$. These reductions seem to be irresponsive to the inflation rate, and show a very stable behaviour. This pattern would appear to confirm some of the findings of Anderson et al. (2012) regarding price decreases, and the possible explanation of having these respond to a different mechanism than the one governing regular price increases; being on 'autopilot' as they call it.

Price increases react more to the overall inflation rate. The clearest one of these relations is the proportion of price quotes increasing each month. The random effects model establishes a positive relation with the frequency and the size of the price increases, being more pronounced in the case of the proportion of price adjustments. Interpreting these coefficients, if the average size of the price increases is $10 \%$ and the inflation rate increases by one percentage point, the size of these price changes would rise to $10.097 \%$. Similarly, for the proportion of price increases, if $10 \%$ of the prices are increasing every month and the inflation rate increases by 1 percentage point, the proportion of prices that increase would go to $10.918 \%$. Looking at these results, it is clear that in Costa Rica the dynamics of price adjustment are driven by the amount of prices that increase every month. While the size of these price increases is also pushed by the overall inflation rate, the average response of the frequency is bigger by a factor of almost ten.

The dynamics of price increases are remarkably compatible with the ones described by an $S s$ decision rule model. In this setting, the firms have a target price each period, and as long as the difference in the target price and the actual price is less than $s$-S, no changes in the price are made due to adjustment costs. When the difference exits this "inaction region", the firms decide to change the price by $S$-s. Time series wise, this implies a constant average price increase, and a positive relation with the overall rate at which the price level increases. This is exactly what is observed in the data.

These findings give support to the conclusions stated in Nakamura and Steinsson (2008) regarding the relation of the price adjustment process and the inflation rate. One of the caveats they pointed out was that while their findings were clear, they had to be analysed carefully due to the low and stable inflation in the United States. This study provides that setting of a higher and more volatile inflation. While it does not exceed the thresholds to consider this a high-inflation economy such as the Mexican and Argentinian cases examined in Gagnon (2009) and Álvarez et al. (2013), it proves to be a setting in which inflation isn't disruptive enough as to have the size of the price changes considerably altered. What is different is the statistically significant relation between the average size of the price increases and the inflation rate. This, however, has a comparatively low effect when put next to that of the fraction of prices being changed.

The heterogeneity found across the product categories is not particularly surprising. Theoretically, it would be expected since different products have different intensity in the usage of inputs, and empirically it had already been documented in various other studies. Costa Rica is no exception in this regard. Larger macroeconomic models have been calibrated both with multiple and single sectors, and the results in Bils and Klenow (2004) and Nakamura and Steinsson (2010) point to this not being particularly troublesome. In their calibrations they use different summary statistics in a single sector model such as the median and they find that these deliver results satisfactorily similar to those of the multiple sector models. As such, it appears to be a feature of this process that, depending on the context, can be mapped into a single sector model without sacrificing much of its end results.

How compatible are these facts with time-dependent price adjustment models? Well, 
not much. A first element to notice is that with a positive inflation rate, time-dependent models such as Calvo's are unable to rationalise price decreases. However, this criticism applies as well to most state-dependent models. One could be tempted to neglect these facts if the price decreases were not as important, but the data advises otherwise. Between 2006 and 2009 price reductions account for $35.87 \%$ of the total price changes and for $42.56 \%$ over the 2010-2013 period, being on average smaller than the price increases by only $13.55 \%$.

According to this analysis, the biggest testament to favour state-dependence is the reaction of the price changes to the inflation rate. In a time-dependent model the only factor that is associated with the price adjustment process is the size of the price changes; the timing of the changes is exogenously determined. The empirical facts beg to differ in this aspect. The random effects analysis clearly shows how the proportion of price changes in a given month is not constant. These proportions (and their expected survival time, implied by the model's flat hazard rates) not only change, but also are significantly correlated with the overall inflation rate. This is evidence that favours a model that endogenises the timing decision of price changes, such as a menu cost model such as the one presented by Golosov and Lucas (2007), or a customer markets specification as in Nakamura and Steinsson (2011).

When contrasting time-dependent specifications with the micro-data in Costa Rica, the balance is tipped in favour of different processes. State-dependence is profiled as a better alternative to match these findings, since the fraction of price quotes that increase each month drive the price adjustment process by a vast majority.

\section{CONCLUDING REMARKS}

This document presents an exploratory analysis of the pricing adjustment process in Costa Rica, evaluating it against two simple pricing models. While this is an exercise that has been performed in different countries, this one adds to the stock of knowledge mainly because of two reasons. The first reason is the fact that this dataset has never been analysed for this purpose before, and as such unveils characteristics of the Costa Rican economy that have not been studied previously. The second one is the establishment of another comparison point for international analyses. Many studies in advanced economies provide a clear picture of what happens when the macroeconomic setting is particularly calm with a low and stable inflation. Other studies mostly in developing economies offer a view on more volatile and uncertain situations. This case proves to be a middle point between these two stages.

The price adjustment process is analysed focusing the attention in four components: the proportion of prices that change every month, and the average size of the change; each for the cases of price increases and decreases since these prove to be quite different processes. Finally, the individual prices are grouped in 73 different categories and studied as a panel in a random effects model for the months starting on July 2006 and finishing on February 2013.

The main points that can be extracted from this analysis are that 1 ) there is considerable heterogeneity between product categories, as expected and confirmed by the econometric analysis. 2) Price decreases (proportion and magnitude) follow a very stable pattern throughout the period of analysis that does not depend on the overall inflation rate. 3) The average size of the price increases is influenced by the overall inflation rate, but by a very small magnitude. 4) The proportion of prices increasing each month is strongly positively correlated with the overall inflation rate. These results point to having the proportion of price increases driving the price adjustment process, and as such time-dependent pricing models do not seem to make the cut when tested against their empirical counterparts.

As mentioned before, this is an exploratory analysis extracting concisely one of the most prominent features of the data. Understanding how prices change in an economy proves to be a valuable tool to evaluate crucial aspects of monetary policy, such as its effectiveness and its welfare effects. There is still much to be analysed from this dataset and to be contrasted with more intricate models, and to understand this phenomenon in general. 


\section{REFERENCES}

Álvarez, F.; M. González-Rozada; A. Neumeyer and M. Beraja. 2013. From Hyperinflation to Stable Prices: Argentina's Evidence on Menu Cost Models. Stanford Center for International Development Working Paper 470. Stanford, United States of America.

Alvarez, L.; E. Dhyne; M. Hoeberichts; C. Kwapil; H. Bihan; P. Lunnemann; F. Martins; R. Sabbatini; H. Stahl and P. Vermeulen. 2005. Sticky Prices in the Euro Area: a Summary of New Microevidence. Journal of the European Economic Association 4 (2-3): 575-584.

Anderson, E.; E. Nakamura; D. Simester and J. Steinsson. 2012. Temporary Sales: On Autopilot and Funded by Frequent Flyer Accounts. Unpublished manuscript, Department of Economics, Columbia University. New York, United States of America.

Aucremanne, L. and E. Dhyne. 2004. How Frequently Do Prices Change? Evidence Based on the Micro Data Underlying the Belgian CPI. European Central Bank, Working Paper Series 0331. Frankfurt, Germany.

Bils, M. and P. Klenow. 2004. Some Evidence on the Importance of Sticky Prices. Journal of Political Economy. 112 (5): 947-985.

Calvo, G. 1983. Staggered Prices in a UtilityMaximizing Framework. Journal of Monetary Economics. 12 (3): 383-398.

Cecchetti, S. 1986. The Frequency of Price Adjustment: A Study of the Newsstand Prices of Magazines. Journal of Econometrics. 31 (3): 255 - 274.

Delgado, F. 2010. Retos de las Políticas Monetaria y Cambiaria: Un Horizonte de Mediano Plazo, p. 111-192. In L. Mesalles and O. Céspedes. Recesión con estabilidad: realineando la senda hacia el futuro. Academia de Centroamérica. San José.

Dhyne, E.; L. Alvarez; H. Le Bihan; G. Veronese; D. Dias; J. Hoffmann; N. Jonker; P. Lunnemann; F. Rumler and J. Vilmunen.
2005. Price Setting in the Euro Area: Some Stylized Facts from Individual Consumer Price Data. European Central Bank, Working Paper Series 0524. Frankfurt, Germany.

Gagnon, E. 2009. Price Setting During Low and High Inflation: Evidence from Mexico. The Quarterly Journal of Economics. 124 (3): 1221-1263.

Galí, J. and M. Gertler. 2007. Macroeconomic Modelling for Monetary Policy Evaluation. National Bureau of Economic Research, Working Paper Series 13542. Cambridge, United States of America.

Golosov, M. and R. Lucas. 2007. Menu Costs and Phillips Curves. Journal of Political Economy. 115: 171-199.

Instituto Nacional de Estadística y Censos. 2006a. Metodología del índice de precios al consumidor. San José, Costa Rica: INEC.

Instituto Nacional de Estadística y Censos. 2006b. Principales características del índice de precios al consumidor. San José, Costa Rica: INEC.

Kashyap, A. 1995. Sticky Prices: New Evidence from Retail Catalogs. The Quarterly Journal of Economics. 110 (1): 245-274.

Klenow, P. and O. Kryvtsov. 2008. StateDependent or Time-Dependent Pricing: Does it Matter for Recent US Inflation? The Quarterly Journal of Economics. 123 (3): 863-904.

Klenow, P. and B. Malin. 2010. Microeconomic Evidence on Price-Setting. National Bureau of Economic Research, Working Paper Series 15826. Cambridge, United States of America.

León, J.; B. Laverde and R. Durán. 2002. Pass through del tipo de cambio en los precios de bienes transables y no transables en Costa Rica. Banco Central de Costa Rica, Documento de Investigación DIE-052002-DI.

Lizano, E. 2007. Reformas financieras y política económica y cambiaria. Academia de Centroamérica, Documentos 18. San José, Costa Rica. 
Medina, J.; D. Rappoport and C. Soto. 2007. Dynamics of Price Adjustments: Evidence from Micro Level Data for Chile. Central Bank of Chile, Working Papers 432. Santiago, Chile.

Nakamura, E. and J. Steinsson. 2008. Five Facts about Prices: A Reevaluation of Menu Cost Models. The Quarterly Journal of Economics. 123 (4): 14151464.

Nakamura, E. and J. Steinsson. 2010. Monetary Non-Neutrality in a Multisector Menu Cost Model. The Quarterly Journal of Economics. 125 (3): 961-1013.

Nakamura, E. and J. Steinsson. 2011. Price Setting in Forward-Looking Customer Markets. Journal of Monetary Economics. 58 (3): 220-233.

Nakamura, E. and J. Steinsson. 2013. Price Rigidity: Microeconomic Evidence and Macroeconomic Implications. National Bureau of Economic Research, Working Paper Series 18705. Cambridge, United States of America.

Palmero, M. and N. Chacón. 2011. Dinámica de ajuste de precios en Bolivia: un análisis con micro-datos. Revista de Análisis del BCB. 14 (1): 79-119.

Rotemberg, J. 1982. Sticky Prices in the United States. Journal of Political Economy. 90 (6): 1187-1211.

Shafer, M. 2005. Re: st: hausman and xthausman after panel fe, re. Stata services, http://www.stata.com/statalist/ archive/2005-08/msg00762.html

Sheshinski, E. and Y. Weiss. 1977. Inflation and Costs of Price Adjustment. The Review of Economic Studies. 44 (2): 287-303.

Snowdon, B. and H. Vane. 2005. Modern Macroeconomics: Its Origins, Development and Current State. Edward Elgar, Cheltenham. 807 p.

Taylor, J. 1980. Aggregate Dynamics and Staggered Contracts. Journal of Political Economy. 88 (1): 1-23.

Walsh, C. 2010. Monetary Theory and Policy. MIT Press, Cambridge. $640 \mathrm{p}$.

Woodford, M. 2008. Information-Constrained State-Dependent Pricing. National Bureau of Economic Research, Working Paper Series 14620. Cambridge, United States of America. 


\section{APPENDIX: ESTIMATION RESULTS}

TABLE 3

COSTA RICA: RANDOM EFFECTS REGRESSION ON AVERAGE PRICE DECREASES 2006-2013

\begin{tabular}{|c|c|c|c|c|c|c|}
\hline $\begin{array}{l}\text { Average } \\
\text { decrease: }\end{array}$ & Coef. & Std. Error & $z$ & Prob $>z$ & \multicolumn{2}{|c|}{$95 \%$ Conf. Interval } \\
\hline Inflation & -0.0001608 & 0.0001781 & -0.90 & 0.3660 & -0.0005098 & 0.0001882 \\
\hline Constant & 0.9379951 & 0.0045834 & 204.65 & 0.0000 & 0.9290119 & 0.9469783 \\
\hline \multirow[t]{3}{*}{ R-sq: } & within & 0.0002 & & \multicolumn{2}{|l|}{ Number of obs. } & 4085 \\
\hline & between & 0.0085 & & \multicolumn{2}{|l|}{ Number of groups } & 73 \\
\hline & overall & 0.0001 & & \multicolumn{2}{|l|}{ Prob > chi-sq } & 0.3664 \\
\hline \multicolumn{2}{|l|}{ Wald chi-sq (1) } & 0.82 & & \multicolumn{2}{|l|}{ Rho } & 0.4560217 \\
\hline \multicolumn{2}{|l|}{ Sigma_u } & 0.03618525 & & \multicolumn{2}{|l|}{ Sigma_e } & 0.03952116 \\
\hline
\end{tabular}

Source: compiled by author.

TABLE 4

COSTA RICA: RANDOM EFFECTS REGRESSION ON AVERAGE PRICE INCREASES 2006-2013

\begin{tabular}{|c|c|c|c|c|c|c|}
\hline $\begin{array}{l}\text { Average } \\
\text { increase: }\end{array}$ & Coef. & Std. Error & z & Prob $>z$ & \multicolumn{2}{|c|}{$95 \%$ Conf. Interval } \\
\hline Inflation & 0.0009666 & 0.0002170 & 4.46 & 0.0000 & 0.0005413 & 0.0013918 \\
\hline Constant & 1.0779240 & 0.0058646 & 183.80 & 0.0000 & 1.0664290 & 1.0894180 \\
\hline \multirow[t]{3}{*}{ R-sq: } & within & 0.0041 & & \multicolumn{2}{|l|}{ Number of obs. } & 4913 \\
\hline & between & 0.0020 & & \multicolumn{2}{|l|}{ Number of groups } & 73 \\
\hline & overall & 0.0026 & & \multicolumn{2}{|l|}{ Prob > chi-sq } & 0.0000 \\
\hline \multicolumn{2}{|l|}{ Wald chi-sq (1) } & 19.85 & & \multicolumn{2}{|l|}{ Rho } & 0.44256347 \\
\hline \multicolumn{2}{|l|}{ Sigma_u } & 0.04742635 & & \multicolumn{2}{|l|}{ Sigma_e } & 0.05322671 \\
\hline
\end{tabular}

Source: compiled by author. 
TABLE 5

COSTA RICA: RANDOM EFFECTS REGRESSION ON THE PROPORTION OF PRICE DECREASES 2006-2013

\begin{tabular}{|c|c|c|c|c|c|c|}
\hline $\begin{array}{l}\text { Average } \\
\text { decrease: }\end{array}$ & Coef. & Std. Error & $z$ & Prob $>z$ & \multicolumn{2}{|c|}{$95 \%$ Conf. Interval } \\
\hline Inflation & 0.0001320 & 0.0002938 & 0.45 & 0.6530 & -0.0004438 & 0.0007078 \\
\hline Constant & 0.0867760 & 0.0113825 & 7.62 & 0.0000 & 0.0644667 & 0.1090852 \\
\hline \multirow[t]{3}{*}{ R-sq: } & within & 0.0000 & & \multicolumn{2}{|c|}{ Number of obs. } & 5683 \\
\hline & between & 0.0292 & & \multicolumn{2}{|c|}{ Number of groups } & 73 \\
\hline & overall & 0.0000 & & \multicolumn{2}{|c|}{ Prob > chi-sq } & 0.6532 \\
\hline \multicolumn{2}{|l|}{ Wald chi-sq (1) } & 0.20 & & \multicolumn{2}{|l|}{ Rho } & 0.60209154 \\
\hline \multicolumn{2}{|l|}{ Sigma_u } & 0.09489475 & & \multicolumn{2}{|c|}{ Sigma_e } & 0.07714406 \\
\hline
\end{tabular}

Source: compiled by author

TABLE 6

COSTA RICA: RANDOM EFFECTS REGRESSION ON THE PROPORTION OF PRICE INCREASES 2006-2013

\begin{tabular}{|c|c|c|c|c|c|c|}
\hline $\begin{array}{l}\text { Average } \\
\text { increase: }\end{array}$ & Coef. & Std. Error & $z$ & Prob $>z$ & \multicolumn{2}{|c|}{$95 \%$ Conf. Interval } \\
\hline Inflation & 0.0091758 & 0.0004680 & 19.61 & 0.0000 & 0.0082586 & 0.0100930 \\
\hline Constant & 0.0877450 & 0.0128125 & 6.85 & 0.0000 & 0.0626330 & 0.1128570 \\
\hline \multirow[t]{3}{*}{ R-sq: } & within & 0.0642 & & \multicolumn{2}{|c|}{ Number of obs. } & 5683 \\
\hline & between & 0.0172 & & \multicolumn{2}{|c|}{ Number of groups } & 73 \\
\hline & overall & 0.0378 & & \multicolumn{2}{|c|}{ Prob > chi-sq } & 0.0000 \\
\hline \multicolumn{2}{|c|}{ Wald chi-sq (1) } & 384.49 & & \multicolumn{2}{|l|}{ Rho } & 0.41783382 \\
\hline \multicolumn{2}{|l|}{ Sigma_u } & 0.10410844 & & \multicolumn{2}{|c|}{ Sigma_e } & 0.12288748 \\
\hline
\end{tabular}

Source: compiled by author

Todos los derechos reservados. Universidad de Costa Rica. Este artículo se encuentra licenciado con Creative Commons Reconocimiento-NoComercial-SinObraDerivada 3.0 Costa Rica. Para mayor información escribir a revista.iice@ucr.ac.cr 